\title{
Serum levels of TNF- $\alpha$ and osteoprotegerin and bone mineral density in patients with Behçet's Disease
}

\author{
Behçet hastalarında serum TNF- a ve osteoprotegerin düzeyi ve kemik kitle yoğunluğu
}

\author{
Ali Kutlucan', Sevket Ercan Tunc², Davut Baltaci ${ }^{3}$, Mehmet Sahin ${ }^{2}$, Mustafa Ozsahin ${ }^{4}$, \\ Recep Sütcï ${ }^{5}$, Fatih Ermis ${ }^{1}$, Harun Süslü ${ }^{6}$
}

\begin{abstract}
Objectives: Osteoporosis is commonly developed due to natural course of Behçet's disease (BD) and therapeutic agents. It was aimed to investigate levels of osteoprotegerin and TNF- $\alpha$ (tumor necrosis factor), and bone mineral density $(B M D)$ and correlation between them in $\mathrm{BD}$.
\end{abstract}

Materials and methods: The study included two groups as the study and the control group. Serum levels of TNF- $\alpha$, osteoprotegerin, osteocalcine, erythrocyte sedimentation rate (ESR), C-reactive protein (CRP), and urinary creatinine and deoxypyridinoline along with BMD level were evaluated and compared. Correlation between TNF- $\alpha$ and osteoprotegerin level was investigated.

Results: The study enrolled $41 \mathrm{BD}$ patients and 36 agedmatched control subjects. Mean age was $42.26 \pm 11.64$ and $41.66 \pm 70.99$, in the study and control groups, respectively. There was no significant difference in body mass index (BMI) of subjects between groups $(p>0.05)$. Level of TNF- $\alpha$ $(p<0.001)$, deoxypyridinoline $(p<0.001)$ and osteocalcine $(p=0.041)$ was significantly higher in the study group compared to the control group. Osteoprotegerin was lower in BD patients, but the difference was not significant $(p>0.05)$. Urinary deoxypyridinoline/ urinary creatinine ratio in patients with BD was significantly higher than those in control group $(p=0.030)$. Patients had significantly lower BMD comparfed to the control group, except L2-L4 vertebral area $(p<0.001$, $p<0.001, p=0.035, p<0.001, p=0.012, p<0.001, p<0.001$ and $p=0.111$, respectively). No correlation was found between TNF- $\alpha$ and osteoprotegerin.

Conclusions: The present study indicated that TNF- $\alpha$ and BMD was negatively correlated with each other and TNF- $\alpha$ had an effect on osteoporotic process in patients with BD. Osteoprotegerin level was not decreased, and not correlated with TNF- $\alpha$.

Key words: Behçet's disease, osteoprotegerin, TNF-a, osteocalcine

\section{ÖZET}

Amaç: Behçet hastalığı (BH)'nın doğal seyri sırasında ya da kullanılan ilaçlara bağlı olarak osteoporoz gelişebilir. Çalışmanın amacı BH'nda osteoprotegerin ve tümor nekroz faktör (TNF- $\alpha$ ) düzeyleri ve bunlar arasındaki korelasyonu araştırmaktır.

Gereç ve yöntem: Çalışmaya, hasta grubu ve kontrol grubu olarak iki grup alındı. TNF-a, osteoprotegerin, osteokalsin, sedimantasyon, CRP, idrar kreatin ve deoksipridinolin düzeyleri ile beraber kemik mineral dansitometrisi (KMD) ölçüldü ve iki grup karşılaştırıldı.

Bulgular: Çalışma grubuna 41 hasta, kontrol grubuna 36 hasta alındı. Çalışma ve kontrol grubunun yaş ortalaması sırasıyla $42.26 \pm 11.64$ ve $41.66 \pm 70.99$ bulundu. Vücut kitle indeksi yönünden iki grup arasında fark bulunmadı. TNF- $\alpha(p<0.001)$, deokspiridinolin $(p<0.001)$ ve osteokal$\sin (p=0.041)$ düzeyleri kontrol grubundan önemli oranda yüksek bulundu. Osteoprotogerin düzeyi hasta grubunda düşüktü ancak anlamlı düzeyde değildi ( $p>0.05)$. İdrar deoxypyridinoline/ idrar kreatinin oranı hasta grubunda kontrol grubuna göre anlamlı yüksekti $(p=0.03)$. Hasta grubun KMD ölçümü; L2-L4 hariç, kontrol grubuna göre anlamlı oranda düşüktü (sırasıyla $p<0.001, p<0.001, p=0.035$, $p<0.001, p=0.012, p<0.001, p<0.001$ ve $p=0.111)$. TNF- $\alpha$ ve osteoprotegerin arasında korelasyon saptanmadı.

Sonuç: Bu çalışmada TNF- $\alpha$ ve KMD arasında negatif korelasyon saptandı ve TNF-a'nın, BH'da osteoporotik süreci etkilediği bulundu. Osteoprotogerin düzeyi düşüklüğü anlamlı değildi ve TNF- $\alpha$ ile korele değildi.

Anahtar kelimeler: Behçet hastalığı, osteoprotegerin, TNF- $\alpha$, osteokalsin

${ }^{l}$ Duzce University, Department of Internal Medicine, Faculty of Medicine, Duzce, Turkey

${ }^{2}$ Suleyman Demirel University, Department of Internal Medicine, Faculty of Medicine, Isparta, Turkey

${ }^{3}$ Duzce University, Department of Family Medicine, Faculty of Medicine, Duzce, Turkey

${ }^{4}$ Duzce University, Department of Physical Medicine and Rehabilitation, Faculty of Medicine, Duzce, Turkey

${ }^{5}$ Suleyman Demirel University, Department of Biochemistry, Faculty of Medicine, Isparta, Turkey

${ }^{6}$ Suleyman Demirel University, Department of Nuclear Medicine, Faculty of Medicine, Isparta, Turkey

Yazışma Adresi /Correspondence: Dr. Ali Kutlucan,

Duzce University, Department of Internal Medicine, Faculty of Medicine, Duzce, Turkey Email: dralikutlu-can@gmail.com

Geliş Tarihi / Received: 16.07.2012, Kabul Tarihi / Accepted: 24.08.2012

Copyright (C) Dicle Tıp Dergisi 2012, Her hakkı saklıdır / All rights reserved 


\section{INTRODUCTION}

Behçet's disease (BD) is a chronic disease with remissions and exacerbations, involving all types of blood vessels. It is multi-systemic and multi-organ involvement disease. ${ }^{1}$ In several studies, it was shown that bone involvement, particularly osteoporosis and osteopenia, is commonly developed in BD due to natural course of disease and agents used for its treatment. ${ }^{2,3}$

Osteoporosis is considered to be an imbalance of the remodeling process, in which bone resorption exceeds bone formation. A growing understanding of this process has shown that factors involved in inflammation are linked to critical factors associated with bone physiology. Elevated levels of tumor necrosis factor $\alpha$ (TNF- $\alpha$ ), interleukine-1 (IL-1), interleukine-6 (IL-6) and interleukine-18 (IL-18) have been found to be critical role in bone and articular pathology. All of them play important role in induction of bone resorption, resulting in decrease in bone mineral density (BMD). ${ }^{4}$ Osteoprotegerin, a member of TNF receptor super-family, is a glycoprotein which has desired efficacy on bone mineral density and metabolism by inhibiting osteoclastic activity and formation. ${ }^{3,5}$

Correlation between osteoprotegerin and cytokines such as TNF- $\alpha$ and interleukins in BD has not been extremely investigated before. In medical literature, this is unique study about osteoprotegerin and its relation with TNF- $\alpha$ on BMD in patients with BD. The purpose of the present study was to evaluate bone mineral density in $\mathrm{BD}$, which is more commonly seen in our country compared to other countries, and to investigate the correlation between osteoprotegerin and TNF- $\alpha$ in osteoblastic and osteoclastic activity. We also aimed to evaluate osteocalcin, deoxypyridinoline and TNF- $\alpha$ level in BD.

\section{MATERIALS AND METHODS}

\section{Study population}

The study and control groups were established in the study. Forty one BD patients who were diagnosed according to the International Study Group criteria and admitted to out-patient clinic of rheumatology were included in the study. All of the patients suffered from mild to moderate BD, and none of them had central nervous system or gastrointestinal involvement, pulmonary lesions or vasculitis. Con- trol group was selected as aged-matched healthy individuals. Age, height and weight of all subjects were recorded and body mass index (BMI) was calculated as weight $(\mathrm{kg}) /$ height $\left(\mathrm{m}^{2}\right)$. The study was conducted by Suleyman Demirel University Hospital within 6-months period. An inclusion criterion was a previous diagnosis of BD. All participitants signed informed consent form before taking part in the study. Exclusion criteria were existence of one of the those diseases: thyroidal diseases such as hypo and hyperthyroidism, parathyroidism, vitamin D deficiency, known post-menopausal and senile osteoporosis, history of steroid use over 3 months or current steroid usage, other immunosuppressant treatment such as anti- TNF- $\alpha$ antibody therapy, drugs which could affect bone metabolism, diabetes mellitus, chronic liver and kidney diseases, menstrual irregularity, and pregnancy.

\section{Biochemical analysis}

In both groups, TNF- $\alpha$, osteoprotegerin (OPG), osteocalcine, thyroid function tests, total testosterone, calcium, phosphorus, ALP, erythrocyte sedimentation rate (ESR), C-reactive protein (CRP), urea, creatinine, fasting glucose, triglyceride, total cholesterol, HDL-cholesterol, ALT, AST levels were assayed in the morning time after an overnight fasting. Urinary creatinine and deoxypyridinoline levels were also assayed at urinary sample that was collected in the morning.

Samples were stored at $-70^{\circ}$ prior to analysis. They were assayed with photometric method using biochemistry auto-analyzer (Aerroset, Abbot, Illinois, USA). Total testosterone and thyroid function tests were measued with method of chemiluminescent immunometric assay (Architech I 2000 Abbot Illinois, USA). Serum osteocalcin was measured with immunometric assay (Immulite Osteocalcin, USA). Urinary deoxypyridinoline (adjusted for creatinine excretion) was measured by a solid phase chemiluminescent enzyme-labeled immunoassay (Immulite Pyrilinks-D, USA). Urinary creatinine and calcium were assayed with modular P 800 Roche auto-analyzer. CRP level was assayed with nephelometric method. ESH was measured in a vacutainer sedimentation tube with Westerngreen method, using the Greiner Labr-Austria device. TNF- $\alpha$ levels were measured with human TNF- $\alpha$ ELISA kit of Biosource International. OPG (BioVendor Laboratory Medicine, Czech Republic) levels were mea- 
sured by commercially available ELISA method according to the manufacturer's instructions.

\section{Bone mineral density measurements}

Bone mineral density at the lumbar spine and hip (femoral neck, Ward's triangle and trochanter) was evaluated by dual x-ray absorptiometry using Norland-XR 2000. The instrument was calibrated daily according to the manufacturer's instructions. BMD data were expressed as grams per centimeter square and standard deviation scores, and compared with BMD values of controls. Osteoporosis and osteopenia were defined by using criteria described by WHO and the International Osteoporosis Foundation. ${ }^{6}$

\section{Statistical analysis}

Data were analyzed using SPSS version 15.0 (Chicago, IL). Numeric variables were stated as mean \pm standard deviation. Categorical variables were stated as frequency and percentage. Variables of independent two groups with normal distribution were analyzed with student's t-test, but nonparametric Kruskal-Wallis $\mathrm{H}$ test was used for variables of independent two groups without normal distribution. Correlation between variables with normal distribution was analyzed with Pearson's correlation analysis. Spearmen's correlation analysis was used for variables without normal distribution. $\mathrm{p}<0.05$ was accepted for statistical significance.

\section{RESULTS}

The study enrolled 41 patients with Behçet's disease (male $=20$ and female $=21$ ) in the study group and 36 aged-matched healthy individuals (male $=16$ and female $=20)$ in control group $(p>0.05)$. Mean age of participants in the study and control groups were $42.26 \pm 11.64$ years and $41.66 \pm 70.99$ years, respectively ( $\mathrm{p}>0.05)$. Mean BMI was $26.11 \pm 3.18$ for the study group and $25.61 \pm 3.24$ for controls $(\mathrm{p}>0.005)$. Mean duration of disease was $5.72 \pm 6.15$ years (range 1-28). All participants' complete blood count and biochemical parameters were tested and shown in Table 1. There were no significant differences between two groups, regarding biochemical parameters. ESR in the study group was observed higher, but difference between two groups didn't reach statistically significant level $(18.31 \pm 15.84 \mathrm{~m} /$ $\mathrm{hr}$ and $14.10 \pm 11.43 \mathrm{~m} / \mathrm{hr}$, respectively; $\mathrm{p}=0.190$ ). Mean CRP level was found to be statistically signif- icant higher in the study group, compared to control group $(15.42 \pm 33.03 \mathrm{mg} / \mathrm{dl}$ versus $4.52 \pm 3.95 \mathrm{mg} / \mathrm{dl}$, respectively; $\mathrm{p}<0.001$ ) (Table 1 ).

Table 1. Comparison of basic biochemical and complete blood count parameters between study and control group

\begin{tabular}{llll}
\hline & Study Group & Control Group & P \\
\hline ESR $(\mathrm{mm} / \mathrm{h})$ & $18.31 \pm 15.84$ & $14.10 \pm 11.43$ & $\mathrm{NS}$ \\
CRP $(\mathrm{mg} / \mathrm{L})$ & $15.42 \pm 33.03$ & $4.52 \pm 3.95$ & $<0.05$ \\
ALP $(\mathrm{U} / \mathrm{L})$ & $235.14 \pm 106.99$ & $201.38 \pm 50.62$ & $\mathrm{NS}$ \\
Calcium $(\mathrm{mg} / \mathrm{dL})$ & $9.64 \pm 0.49$ & $9.87 \pm 0.38$ & $\mathrm{NS}$ \\
Phosphor $(\mathrm{mg} / \mathrm{dL})$ & $3.51 \pm 0.62$ & $3.58 \pm 0.61$ & $\mathrm{NS}$ \\
ALT $(\mathrm{U} / \mathrm{L})$ & $28.21 \pm 16.68$ & $22.02 \pm 6.90$ & $\mathrm{NS}$ \\
Hemoglobin $(\mathrm{g} / \mathrm{dL})$ & $13.8 \pm 1.8$ & $13.9 \pm 1.4$ & $\mathrm{NS}$ \\
Hematocrit $(\%)$ & $39.6 \pm 4.9$ & $40.0 \pm 3.9$ & $\mathrm{NS}$ \\
$\begin{array}{l}\text { Body Mass Index } \\
\left(\mathrm{kg} / \mathrm{m}^{2}\right)\end{array}$ & $26.11 \pm 3.18$ & $25.61 \pm 3.24$ & $\mathrm{NS}$ \\
\hline
\end{tabular}

ESR: Erythrocyte sedimentation rate, CRP-C: reactive protein, ALT: alanine transaminase, NS: not significant

In Table 2, levels of TNF- $\alpha$, osteocalcine, deoxypyridinoline, osteoprotegerin, urinary calcium and deoxypyridinoline/urinary creatinine ratio of subjects in the study and control group was shown. TNF- $\alpha(1.94 \pm 1.40 \mathrm{pg} / \mathrm{ml}$ versus $0.90 \pm 0.68 \mathrm{pg} / \mathrm{ml}$, $\mathrm{p}<0.001)$, deoxypyridinoline $(8.54 \pm 3.12 \mathrm{pmol} / \mathrm{L}$ versus $4.63 \pm 0.48 \mathrm{pmol} / \mathrm{L}, \mathrm{p}<0.001)$ and osteocalcine $(32.02 \pm 44.60 \mathrm{ng} / \mathrm{ml} ; 19.91 \pm 9.05 \mathrm{ng} / \mathrm{ml}$, $\mathrm{p}=0.041$ ) was found to be statistically significant higher in the study group. Although osteoprotegerin level was detected as lower in patients with BD, it wasn't found statistically significant $(8.66 \pm 1.70$ $\mathrm{pmol} / \mathrm{L}$ versus $9.05 \pm 1.85 \mathrm{pmol} / \mathrm{L}, \mathrm{p}>0.05$ ). Urinary deoxypyridinoline/urinary creatinine ratio in patients with BD compared to control group was found to be statistically significant higher $(0.14 \pm 0.30$ $\mathrm{nmol} / \mathrm{mmol}$ versus $0.05 \pm 0.26 \mathrm{nmol} / \mathrm{mmol}, \mathrm{p}=0.03$ ); but spot urinary calcium level wasn't found significantly higher in the study group $(10.20 \pm 8.85 \mathrm{mg} / \mathrm{dl}$ versus $11.88 \pm 10.41 \mathrm{mg} / \mathrm{dl}, \mathrm{p}>0.05)$.

In Table 3, femur neck $\mathrm{T}$ and $\mathrm{Z}$ score, vertebra (L1-L4) T and Z score, femur neck, great trochlear, Wards' triangle and L2-L4 vertebral BMD according to the study and control group were shown. When BMD measurement of all subjects was evaluated, all parameters in patients with BD were observed statistically significant lower than control group, except L2-L4 vertebral area $(\mathrm{p}<0.001, \mathrm{p}<0.001$, 
$\mathrm{p}=0.035, \mathrm{p}<0.001, \mathrm{p}=0.012, \mathrm{p}<0.001, \mathrm{p}<0.001$ and $\mathrm{p}=0.111$, respectively).

Correlation of TNF- $\alpha$ with osteoprotegerin, deoxypyridinoline level and BMD measurements in patients with BD was shown. No any significant correlation was observed between TNF- $\alpha$ and others (Table 4).

Table 2. Comparison of bone turnover markers and TNF- $\alpha$ between study and control group

\begin{tabular}{|c|c|c|c|}
\hline & $\begin{array}{l}\text { Study Group } \\
(n=41)\end{array}$ & $\begin{array}{l}\text { Control Group } \\
(n=36)\end{array}$ & $P$ \\
\hline Osteocalcine (ng/mL) & $32.02 \pm 44.60$ & $19.91 \pm 9.05$ & 0.041 \\
\hline Osteoprotegerin (pmol/L) & $8.66 \pm 1.70$ & $9.05 \pm 1.85$ & NS \\
\hline $\begin{array}{l}\text { Deoxypyridinoline } \\
\text { (nmol) }\end{array}$ & $8.54 \pm 3.12$ & $4.63 \pm 1.48$ & $<0.001$ \\
\hline$(T N F-\alpha)(p g / m L)$ & $1.94 \pm 1.40$ & $0.90 \pm 0.68$ & $<0.001$ \\
\hline $\begin{array}{l}\text { Urinary Deoxypyridinoline/Cr } \\
\text { (nmol/mmol) }\end{array}$ & $0.14 \pm 0.30$ & $0.05 \pm 0.26$ & 0.032 \\
\hline $\begin{array}{l}\text { Spot Urinary Ca Excretion } \\
(\mathrm{mg} / \mathrm{dL})\end{array}$ & $10.20 \pm 8.85$ & $11.88 \pm 10.41$ & NS \\
\hline
\end{tabular}

TNF-a: Tumor necrosis factor-alpha; NS: not significant

Table 3. Comparison of bone mass density measurements between study and control group

\begin{tabular}{clll}
\hline & \multicolumn{2}{l}{$\begin{array}{l}\text { Study Group } \\
\end{array}$} & \multicolumn{2}{l}{ Control Group } \\
& $(\mathrm{n}=41)$ & $(\mathrm{n}=36)$ & \\
\hline Femur neck T score & $-0.89 \pm 1.32$ & $0.10 \pm 0.70$ & $<0.001$ \\
Z score & $-0.35 \pm 0.97$ & $0.70 \pm 0.73$ & 0.01 \\
Vertebra (L1-L4) T score & $-0.87 \pm 1.25$ & $0.08 \pm 0.68$ & 0.035 \\
Z score & $-0.56 \pm 1.15$ & $0.05 \pm 0.69$ & $<0.001$ \\
Femur neck BMD (gr/cm $\left.{ }^{2}\right)$ & $0.84 \pm 0.13$ & $0.90 \pm 0.08$ & 0.012 \\
Trochanter BMD (gr/cm $\left.{ }^{2}\right)$ & $0.69 \pm 0.11$ & $0.85 \pm 0.06$ & $<0.001$ \\
Wards BMD (gr/cm $\left.{ }^{2}\right)$ & $0.65 \pm 0.13$ & $0.83 \pm 0.05$ & $<0.001$ \\
L2-L4 BMD $\left(\mathrm{gr} / \mathrm{cm}^{2}\right)$ & $0.98 \pm 0.16$ & $1.04 \pm 0.11$ & 0.111 \\
\hline
\end{tabular}

L: lumbar vertebra, BMD: Bone mineral density

Table 4. Correlation of TNF- $\alpha$ with measurements of bone mass density and bone turnover markers of deoxypyridinoline and osteoprotegerin

\begin{tabular}{llc}
\hline & \multicolumn{2}{c}{ TNF- $\alpha$} \\
\cline { 2 - 3 } & \multicolumn{1}{c}{$r$} & $\mathrm{p}$ \\
\hline Deoxypyridinoline & -0.257 & 0.104 \\
Osteoprotegerin & 0.194 & 0.224 \\
Femur T score & -0.75 & 0.275 \\
Femur Z score & -0.14 & 0.929 \\
Vertebra T score & -0.180 & 0.260 \\
Vertebra T score & -0.018 & 0.911 \\
Femur neck BMD & -0.070 & 0.666 \\
Trochanter BMD & -0.170 & 0.287 \\
Wards BMD & -0.142 & 0.377 \\
L2-L4 BMD & -0.109 & 0.479 \\
\hline
\end{tabular}

BMD: Bone mineral density

\section{DISCUSSION}

In the present study, we investigated osteoprotegerin activity and it's relation with TNF- $\alpha$ in BD. Osteoprotegerin which is an indicator for osteoblastic activity, was found to be reduced in patients with BD compared to healthy individuals, but reduction wasn't statistically significant. We also found correlations between TNF- $\alpha$ and bone mineral density measurement in the study group.

As a result of causal or a final stage of $\mathrm{BD}$, bone breakdown is inevitable when untreated properly. Natural course of BD, drugs used in its treatment, cytokines which play role in its etiopathogenesis may all lead to osteoporosis. Osteoporosis is a result of disequilibrium between bone formation and breakdown. For bone remodeling, equilibrium can be provided by interaction between osteoclasts, osteoblasts, bone marrow stromal cells and fibroblasts, macrophages and T-lymphocytes. ${ }^{3}$ The relationship between $\mathrm{BD}$ and osteoporosis has not been studied intensively before but there are many studies on other rheumatic diseases such as familial Mediterranean fever and rheumatoid arthritis, which have similar etiopathogenesis with BD. ${ }^{7}$

Behçet's disease is a chronic and complex disorder. Many organs can be involved. During its natural course many cytokines such as IL-1, IL-6 and TNF- $\alpha$ are secreted into circulation. These are known as the most powerful stimulators for bone breakdown. TNF- $\alpha$ is one the stimulators known as the most potent. Many studies have shown that it is effective in bone breakdown. ${ }^{3,8,9}$ Evereklioglu et al. studied IL-1 and TNF- $\alpha$ and found IL-1 levels low in patient and control group, whereas, TNF level significantly elevated in patients with BD. ${ }^{10}$ In our study, we studied only TNF- $\alpha$ and found TNF- $\alpha$ level lower in the case group compared to the healthy control group, similar to the former study. Osteocalcin is biological marker indicating bone formation process and relatively well correlated with increase in bone mineral density. In several studies, on rheumatoid diseases, osteocalcin level was found to be decreased. Gursoy et al. studied on relation between rheumatoid arthritis and osteocalcin along with bone mineral density. ${ }^{11}$ They found osteocalcin level higher in patient group compared with control group. On the other hand, Kirnap et al. studied relation between cytokines and $\mathrm{BD}$, and found no correlation between osteocalcin and cytokines. ${ }^{3}$ 
However, we found osteocalcin level significantly higher and a weak positive correlation between osteocalcin and TNF- $\alpha$ in patients with BD, indicating increased bone turnover.

Deoxypyridinoline is a degradation product of collagen in the urine, and has been used as marker in the diagnosis and follow-up of osteoporosis. It has been found to be a sensitive and specific marker indicating bone resorption. ${ }^{12,13}$ Urinary deoxypyridinoline hasn't been intensively studied on osteoporosis in patients with $\mathrm{BD}$. Tekin et al. studied bone turnover markers of patients with $\mathrm{BD}$, including osteocalcin, urinary deoxypyridinoline and BMD. They found no significant differences between patient and control group. ${ }^{4}$ Kirnap et al. studied bone markers in patients with $\mathrm{BD}$ and also found no significant difference. ${ }^{3}$ However, we found significant difference in urinary deoxypyridinoline level and urinary deoxypyridinoline/urinary creatinine between normal controls and patients with BD. This result might be due to our study design and patients' clinics, because deoxypyridinoline could be affected by inflammatory state of natural course of disease.

Majority of the patients were above level of osteoporotic and osteopenic value defined by WHO. ${ }^{14,15}$ In the present study, on the other hand, $\mathrm{T}$ and $\mathrm{Z}$ scores of femur and vertebra in patients with $\mathrm{BD}$ were significantly lower than control group. BMD measurements of femur neck, Trochlear and Wards' triangle except L2-L4 spine in the study group were significantly lower, compared with control group. It indicated that bone resorption increased in our patients. Bicer et al. found and reported no significant differences between control and BD patients. ${ }^{2}$ Kirnap et al. reported significant difference in bone mineral density, T score and scores of L2-L4, but not in other region. ${ }^{3}$ We found significant difference in all regions of BMD measurements except L2-L4 vertebra BMD.

Cytokines such as TNF- $\alpha$ have osteoporotic effect on bony structure, increasing bone turnover. In several studies, it was shown that cytokines such as IL- 1 and TNF- $\alpha$ increased bone resorption in rheumatologic diseases. However, there are a few studies on correlation between bone mineral density and cytokines in BD. Osteoporotic process due to cytokines such as TNF- $\alpha$ and interleukins in the BD has not been extremely investigated before. There are a few studies in the literature. Particularly, they are from Turkey. Akdeniz et al. reported that serum levels of IL-2, IL-6, TNF- $\alpha$, and nitric oxide concentrations in patients with $\mathrm{BD}$ were found to be statistically significant higher than controls. ${ }^{16} \mathrm{We}$ found non-significant negative correlation between TNF- $\alpha$ and bone mineral density measurements.

Osteoprotegerin is a basic glycoprotein and cytokine receptor, belonging to tumor necrosis factor super family member. It can reduce the production of osteoclasts by inhibiting osteoclasts differentiation. It specifically acts on bone, increasing bone mineral density and bone volume. ${ }^{17,18}$ In an experimental animal study conducted by Schett et al., it was shown that bone resorption induced by increased TNF- $\alpha$ could be inhibited by osteoprotegerin. ${ }^{5}$ In the present study, we studied on osteoprotegerin level and correlation between TNF- $\alpha$ and osteoprotegerin. We found that osteoprotegerin level was increased in our patients, but it didn't reach statistically significant level compared to control group. We expected that osteoprotegerin would be decreased under TNF- $\alpha$ secretion, so we would have suggested antiTNF- $\alpha$ treatment in patients with BD to increase osteoprotegerin. However, osteoprotegerin level has not been decreased while TNF- $\alpha$ increased. It might be due to compensation mechanism respect to TNF$\alpha$-induced bone turnover.

There are some limitations and highlights for our study. Some reports also suggested that duration of chronic diseases is negatively associated with BMD at site in patients with rheumatoid arthritis. ${ }^{19}$ However, studies didn't found any association between BMD and BD. In the present study, we didn't investigate correlation or association between duration of disease and BMD. In prospective studies, the course of the disease and treatment effects on disease along the time can be followed up and some outcomes can be obtained. But, as our study was designed as cross-sectional, we could not observe any prognostic features or treatment effects on course of BD. Sample size of this study was relatively small. Further studies with larger sample in size are needed for more confidential and rational results.

Highlights of the present study can be stated as factors such as age, BMI and sex, which can cause osteoporosis, were excluded. Isolated effect of TNF- $\alpha$ on bone turnover was evaluated. This is the first study which evaluated correlation between osteoprotegerin and TNF- $\alpha$ in BD. 
In conclusion, the study indicated that bone turnover and TNF- $\alpha$ levels increased in patients with BD and also it was shown that TNF- $\alpha$ and BMD were negatively correlated. We concluded that TNF- $\alpha$ had an effect on osteoporotic process in patients with BD.

\section{Conflict of Interest}

There is no conflict of interest between the authors.

\section{Ethics}

The study was approved by ethic committee of our institute, Medical Faculty, Suleyman Demirel University.

\section{Support}

The resent study was financially supported by coordination unit of Science Investigation Project of University, Suleyman Demirel University. (Project No: 933-M-04)

\section{REFERENCES}

1. Kalayciyan A, Zouboulis C. An update on Behçet's disease. J Eur Acad Dermatol Venereol 2007; 21(1):1-10.

2. Bicer A, Tursen U, Kaya TI, et al. Bone mineral density in patients with Behçet's disease. Rheumatol Int 2004; 24(6):355-8.

3. Kirnap M, Calis M, Kaya N, Muhtaroglu S. Is the Behcet's disease a risk factor for osteoporosis and is relation to cytokines? Bratisl Lek Listy 2010; 111(6):340-4.

4. Tekin NS, Ozdolap S, Sarikaya S, Esturk E, Gumustas S. Bone mineral density and bone turnover markers of patients with Behçet's disease. J Eur Acad Dermatol Venereol 2007; 21(1):25-9.

5. Schett G, Redlich K, Hayer S, et al. Osteoprotegerin protects against generalized bone loss in tumor necrosis factortransgenic mice. Arthritis Rheum 2003; 48(7):2042-51.

6. Kanis JA, McCloskey EV, Johansson H, Oden A, Melton LJ, Khaltaev N. A reference standard for the description of osteoporosis. Bone 2008; 42(3):467-75.

7. Yuksel S, Samli H, Colbay M, et al. Increased serum osteoprotegerin levels associated with decreased bone mineral density in familial Mediterranean fever. Tohoku J Exp Med 2009; 217(4):321-7.

8. Nanes MS. Tumor necrosis factor-alpha: molecular and cellular mechanisms in skeletal pathology. Gene 2003; 12(4):1-15.

9. Sophie R, Philippe O. Bone loss: factors that regulate osteoclast differentiation-an update. Arthritis Res 2000; 2(6):451-6.

10. Evereklioglu C, Er H, Türköz Y, Cekmen M. Serum levels of TNF-alpha, IL-2, IL-6, and IL-8 are increased and associated with elevated lipid peroxidation in patients with Behçet's disease. Mediators Inflamm 2000; 11(2):87-93.

11. Gürsoy S, Adam M. Romatoid artritli olguların fonksiyonel durumu, hastalık süresi, esh, kmy değeri, osteokalsin ve crp düzeyi arasında korelasyonların varlığının araştırılması. Turk J Rheumatol 2000; 15(3):167-71.

12. Sarikaya S, Basaran A, Tekin Y, Ozdolap S, Ortancil O. Is osteoporosis generalized or localized to central skeleton in ankylosing spondylitis? J Clin Rheumatol 2007; 13(1):204.

13. Mihaljević I, Mudri D, Smolić R, Smolić M, Tucak-Zorić $\mathrm{S}$. Biochemical bone turnover markers: significance in patients with osteoporosis. Coll Antropol 2009; 33(2):21-4.

14. Genant HK, Cooper C, Poor G, et al. Interim report and recommendations of the World Health Organization taskforce for osteoporosis. Osteoporos Int 1999; 10(4):259-64.

15. Kanis JA, Delmas P, Burckhardt P, Cooper C, Torgerson D. The European Foundation for Osteoporosis and Bone Disease: Guidelines for diagnosis and management of osteoporosis. Osteoporos Int 1997; 7(4):390-406.

16. Akdeniz N, Esrefoglu M, Keles MS, Karakuzu A, Atasoy M. Serum interleukin-2, interleukin-6, tumor necrosis factor-alpha and nitric oxide level in patients with Behçet's disease. Ann Acad Med Singapore 2004; 33(5):596-9.

17. Reid P, Holen I. Pathophysiological roles of osteoprotegerin (OPG). Eur J Cell Biol 2009; 88(1):1-17.

18. Simonet WS, Lacey DL, Dunstan CR, et al. Osteoprotegerin: a novel secreted protein involved in the regulation of bone density. Cell 1997; 89(2):309-19.

19. Kroot EJ, Nieuwenhuizen MG, de Waal Malefijt MC, et al. Change in bone mineral density in patients with rheumatoid arthritis during the first decade of the disease. Arthritis Rheum 2001; 44(6):1254-60. 